\title{
Mina Loy and Bikini Kill: Hidden Identities in Feminist Politics Marina Claveria*, Comparative Literature
}

\begin{abstract}
This paper reads the poetry of Mina Loy alongside her Feminist Manifesto (1914) as an expression of personal politics that would come to the forefront of third-wave feminism. By looking at her more expressive works of poetry we are given insight into her personality. When read alongside her politics, as stated in her manifesto, we see how personal desires as well as social pressures complicate her lived politics. Using this as the framework, the paper then looks at the music and publications of the riot grrrl band Bikini Kill to show how the strained relationship between a feminist's personal life and politics would later be embodied in feminist art. I argue that the performative and participatory aspects of riot grrrl allowed Bikini Kill to embody the inseparability of women's politics from their personal lives-something Loy acknowledged on paper, but that her historical period would keep her from ever actualizing.
\end{abstract}

Some people think little girls should be seen and not heard

But I think

Oh Bondage Up Yours!

-X-Ray Spex (1977)

The internal conflicts expressed in Mina Loy's poetic cycle "Songs to Joannes" (1917) and in her Feminist Manifesto (1914) anticipate problems that surface in second and third wave feminism, namely those concerning the idea that the personal is political. These problems are laid out in terms of a woman's challenge to achieve equality while finding fulfillment in romance and in feminine expression (in her manifesto, Loy refers to this as the false binary of "the mistress \& the mother"). About seventy years later the riot grrrl band Bikini Kill addressed this dichotomy through their music and in their zines (self-produced magazines). The idea of the personal as political assumes that politics are not isolated to legislation, but that systematic oppression operates through the politics of personal interactions as well. Therefore, equality can only be achieved when it is re-enforced by the social norms that govern personal interactions. In order to read feminist work, acknowledging the personal as political, we must acknowledge the importance of the differences between personal and public mediums of expression, such as the difference in

\footnotetext{
* Marina Claveria, a junior majoring in Comparative Literature, is minoring in both Spanish and Women's and Gender Studies. After graduation, she plans to teach and stay hungry for more books to read, and things to write. She would also like to play in a punk band at some point. Please send correspondence to claveriamarina@gmail.com.
} 
creative space between Loy's manifesto and her poetry. I argue that the performative and participatory aspects of riot grrrl allowed Bikini Kill to embody the inseparability of women's politics from their personal lives-something Loy acknowledged on paper, but that her historical period would keep her from ever actualizing.

Loy's Feminist Manifesto provides insight into her radical, yet nuanced, feminism, thereby providing a lens by which to read her poetry. The two act as supplements to one another, in that the manifesto lays out her politics, and the poetry provides a more ambiguous medium in which the complications of living these politics is expressed. Loy's first wave feminist contemporaries ignored the poignantly philosophical politics she expressed in her manifesto. Too concerned with legislated inequalities, they were fighting for changes within a system that would remain inherently male-centric, whether or not women were given the right to vote. It was still a man's vote to give, or to extend to women. This power structure sets up an inevitable dichotomy in which a woman's liberation is almost always at odds with her romantic relationships (Loy focuses on heterosexual relations). The question Loy explores, in both her poetry and manifesto, is whether or not one can live life as a fulfilled feminist and a fulfilled woman. These are not necessarily one in the same, when one is born into a social system that continually defines women as inferior to men. Self-aware of the confusion that could come along with her multi-faceted perspective, she told her friend and literary critic Carl Van Vechten that she felt feminine politics, "in a cosmic way that may not fit in anywhere" (Burke 187). It was these "cosmic" politics that surface in her poetry-a self-conscious incongruity of identity between the "mistress \& the mother"-two coexisting sides of Loy that could never surface simultaneously.

In her manifesto, Loy presents the ways in which women's oppression is rooted in their sexualities. She was once quoted as saying, she knew, "nothing about anything but life-\& that is generally reducible to sex" (Burke 191). Loy places sex at the forefront, looking at the ways in which the moralization of sex functions to subjugate women. It is the duty of women to reject society's moralization of sex, in order to bring about "absolute demolition" to patriarchal structures (Loy 153). Her call to destroy the system, rather than work within it to bring about change, differentiated Loy from her first wave feminist contemporaries. Aware of the radical nature of her politics, she acknowledged the complications that arose when true equality is fought for. Loy knew there must be personal sacrifices made towards ideas of romantic love in order for equality beyond the legislative scope to ever be realized. It is a woman's challenge to find mutually equitable love with a man while functioning within a society that is structured in a way that divides the partners participating in loving relationships into the role of the subject, and that of the object.

In her Feminist Manifesto (1914), Loy presents the way in which women are oppressed through the patriarchal formation of a subject-object dynamic between women and men. Loy defines "othering" in its most basic sense-as the act of recognizing one's place in the world through identifying and recognizing what one is not. Othering is a political act in that it allows one to assert superiority over another through consciousness of difference. This idea is inherent to her explanation of dominant social structures, in which male is the norm, and female is the other. Woman is not man; therefore, the lens that larger society looks through is that of the man. Man defines what he is, in noting that woman is different from himself. In doing this, he must 
recognize the woman as an object, through which he situates himself in the world, rather than as another human being, which consequently directs the relationship towards the subject-object dynamic. If it is true, as Loy writes in her manifesto, "The value of man is assessed entirely according to his use or interest to the community, the value of woman, depends entirely on chance"-hopefully a woman will be lucky enough to strike the interest of a man (Loy 155).

If man is the image, and woman the negative image, woman's existence relies entirely on man's composition. Loy explains how women are then challenged to battle the "theoretical valuation of their sex as relative impersonality," or rather, to define what they are, instead of what they are not (Loy154). The relativity Loy talks about is subjectivity of a woman being given worthher definition is dependent on the man comparing himself to her, rather than any intrinsic characteristic. The standard is male, and in not being male, women are deemed inferior by patriarchal standards. In this system women are diminished to isolated qualities, never functioning as independent agents. Consequently they remain unengaged with their full femininity. Loy's femininity is not the hegemonic ideal of the passive housewife. She defines femininity as a quality in which the identities of "the mistress, \& the mother" do not operate independently of one another (Loy 154). This was Loy's take on the early twentieth century feminist ideal of the "New Woman" and her emerging social roles-she was working more, going to school more, and asserting herself socially. Instead of compartmentalizing female sexuality, defining it as immoral, and setting it aside from the self, Loy argues women ought to embrace sexuality as an integral part of themselves. I argue that this is much stronger an expansion of social roles than the average "New Woman" was fighting for. Loy would not settle for simply being allowed in the work place, she wanted full and blatant sexual liberation.

Returning to the subject-object dynamic, we can see patriarchy's roots in the antiquated relationship between lord and subject. To keep this relationship functioning, patriarchy compartmentalizes women, making it much easier to hyper-sexualize them. As mentioned above, her identity is polarized into one of two archetypes: either the "mistress" or the "mother." Women's worth is held in their ability to bear and care for children yet they are not allowed to express that sexuality inherent to the childbearing process. The false binary inscribes the notion of a woman's "physical purity," essentially objectifying the woman by reducing her substance to the construct of virginity alone. No longer recognized for herself, or for her character, a woman is either "a virgin," or "not a virgin." Consequently her personality is no longer decipherable from her perceived purity, because in lacking virginity, she lacks all worth. She is no longer able to achieve society's ultimate goal of finding a man to marry, "as a thank offering for her virginity" (Loy 155). Realizing "that there is nothing impure in sex-except the mental attitude to it," Loy recognizes this moral code as arbitrary (Loy 155). It can be done away with, because its justification loses all worth when taken out of the oppressive subject-object dynamic. If the subject-object dynamic is rejected, the method for defining women can no longer be virginity alone. A woman's selfhood could not be reduced to the presence or absence of a single quality, such as virginity. She could be powerful-an agent of sex, motherhood, and character-thereby giving life to her entire person. 
I want to continue to look at Loy's feminism by presenting Loy's poetry as an inherently personal account of her own attempt to assert agency through sex, motherhood, and characteran attempt to break down the false binary that the patriarchy creates for women of "the mistress \& the mother," as explained in her manifesto (Loy 155). In this false binary woman is caught in the middle-shamed for her sexuality yet prized for her childbearing abilities inherent to sex. In poem I, Loy removes morality from human sexuality by presenting a sexualized satire of traditional love. She employs a character named Pig Cupid to depict sex as amoral, expressing contempt for convention. The poem begins with a series of fragments, the first line reading, "Spawn of fantasies." There is a tension between spawn, something clinical and infesting, and the notion of fantasies, which are something both desired and sentimental. "Spawn" alludes to the idea that the child is the unwanted burden of the mother; a parasite of sorts, given that the child is sustained by the mother but receives all of the intrinsic value. Continuing with the physical, her use of fragments at line 3 enhances the carnality of the poem embodied in Pig Cupid:

Spawn of Fantasies
Silting the appraisable
Pig Cupid his rosy snout
Rooting erotic garbage
"Once upon a time"
Pulls a weed white star-topp
Among wild oats sown in mu
I would an eye in a Bengal
Eternity in a sky-rocket
Constellations in an ocean
Whose rivers run no fresher
Than a trickle of saliva
These are suspect places
I must live in my lantern
Trimming subliminal flicker
Virginal to the bellows
Of Experience

Coloured glass

Pigs connote filth and base lowliness. Countering this connotation through the use of the name Cupid, she upsets the words' natural associations. The language forces a compromise between their usual associations and the societal notion of ideal love bound up in the name Cupid. This love perceived as perfect and wholly moral is emptied of human decency and flattened to the level of the animal. In line 4, which contains the metaphor "Rooting erotic garbage," the word "rooting" takes on multiple meanings. In the context of Pig Cupid, it serves to mean digging around (as in a trough) - the male sex organ becoming a snout. Looking at the noun form of the word, "root" Loy points to the inherent nature of sexual desire. It is rooted within us. Through this she proposes the possibility that sex and love are not separate from one another, and that this false differentiation is merely a construct. She plays with society's tendency to name the sexual as dirty; Volume 6 Issue 1 Spring 2014 
but if sex equals love, and sex equals dirty, here love becomes dirty. As she mentions in her manifesto, the virtue of sexual purity is something that must be given up in exchange for a woman's self-respect.

Now let us consider the definitive break in the poem where Loy counters the overtly sexual "mistress" personality, with the nuance of her own embedded sentimentality: contrasting the eroticism of "Pig Cupid," Loy inserts herself at line 8 as she goes through a number of metaphors explaining love. I say Loy, and not the speaker, because the intimate details of her poetry support the claim that Loy and the speaker are one. The first metaphor "Bengal light" is noteworthy, because it refers to flares used for signaling in a maritime setting. Loy plays with the double meaning of the words "I" and "eye," hinting that she herself becomes an "eye" left to perceive this grand image of love as it burns out before her. Continuing with these rocket and ocean metaphors, Loy presents two impossible images of the uncontainable-"eternity in a sky-rocket" focuses especially on the ephemeral nature of love, as she watches the supposedly eternal explode in a moment before her. She presents these beautiful metaphors only to go on to say, "Whose river runs no fresher / than a trickle of saliva." Bringing focus to the body with "saliva," Loy emphasizes the paradoxical nature of love, as not only an inner struggle between philosophies, but between the mind and the body. In line thirteen she forefronts the inevitable realization that love cannot last, declaring that, "These are suspect places." In other words, the places in which love is idealized, or taken out of context of the sexual, should be questioned. Animalistic sexual desire and fairy-tale love can only coexist for so long. The word "place" becomes important, because it differentiates one space from another. This division of space mirrors the division between Loy's identities as "mistress" and "mother." Both Loy's definition of her self, and of love paradoxically morph and run together as her politics and sentiments find themselves continually in opposition with one another.

The push and pull to define an identity manifests itself within the poems like a peek into Loy's own pseudo-neurotic internal dialogue. Her poetry tells the story of a feminist trying to live sexually without shame, but also contains the story of a woman desirous of the same sentimental love that would shame her. This woman is Loy herself. Loy the poet was Loy the controversial speaker, and because of this, we must read her work personally, nearing on the side of the autobiographical. By disclosing herself as the speaker through intimate details that mirror her personal life (see Becoming Modern and footnotes in The Lost Lunar Baedeker) she is able to express a philosophical dichotomy validated as subjectively true, largely because it is Loy's own lived experience-it is her account of trying to live by an ethic-feminism more easily seen in black and white when isolated to paper than when lived out.

With the idea of Loy's "mistress and the mother" in mind, I would like to display the relevance of Loy's argument in the more contemporary context of the third-wave 1990's feminist punk 
movement riot grrl, examining how public stage performance and personal zines allowed these riot grrrls to embody both identities in their movement, by recognizing that the personal is political. These women realized that it was not only national politics being run by men, but even within the supposedly radical culture of punk, sexism was an issue that must be addressed. Riot grrrl grew out of a desire to see

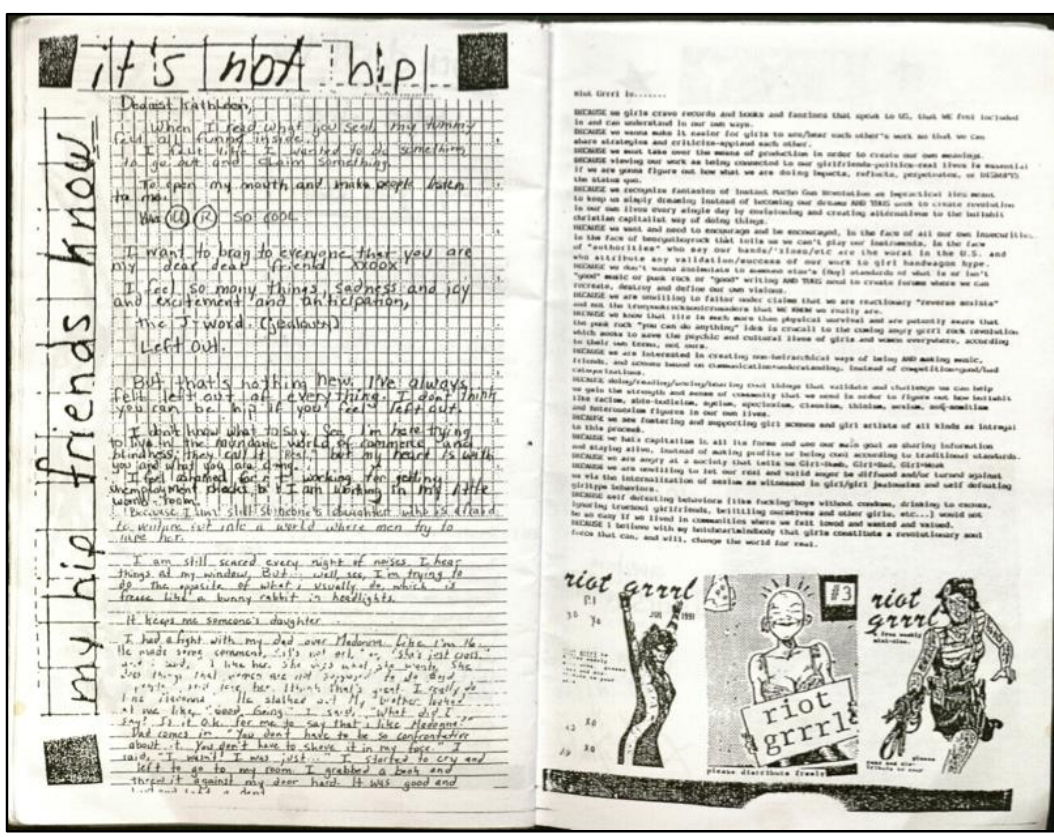

Figure 1: The Riot Grrrl Manifesto, as published in zine \# 2. women represented in the punk scene, but began to encompass much more than music in its goal to create an accessible space to explore their identities in an alternative space to the patriarchal status quo. As stated in the riot grrrl manifesto, the group rejected any system that said "Girl = Dumb, Girl = Bad, Girl = Weak" (Bikini Kill Zine \#2). Riot grrrl's do-it-yourself ethic destroyed the lines that existed between the personal and the political in earlier feminisms. It was abrasive screaming, not knowing how to play an instrument but nonetheless saying "let's start a band," and teen feminists putting out zines in isolated farming towns. When engaging personal politics, Mina Loy only went so far as to raise internal consciousness. Riot grrrl made these complex politics its cause, continually defining and redefining what it meant to be a woman in a patriarchal society through their art.

Riot grrrl's most well known band was Bikini Kill, formed in 1990 in Olympia, Washington. I will look at the ways in which inclusion of the personal both strengthened and complicated Bikini Kill's politics by looking at their zines, lyrics, and wild stage performance by front woman Kathleen Hanna. Riot grrrl had no defined rules or leaders; nevertheless, Bikini Kill would become an important figurehead. I would like to first frame their music within the context of their zines. In Bikini Kill Zine \# 2 (1991), the band states that riot grrrl matters:

BECAUSE we know that life is much more than physical survival and are patently aware that the punk rock you can do anything idea is crucial to the coming angry grrrl rock revolution which seeks to save the psychic and cultural lives of girls and women everywhere, according to their own terms, not ours. (Zine \#2). 
Its sense of collective energy, and validation of each individual's experience valued and invited young women to live out their philosophies-it was not a feminism isolated to bookshelves. All you needed to contribute to this community was the willpower to change the status quo, and access to a Xerox machine.

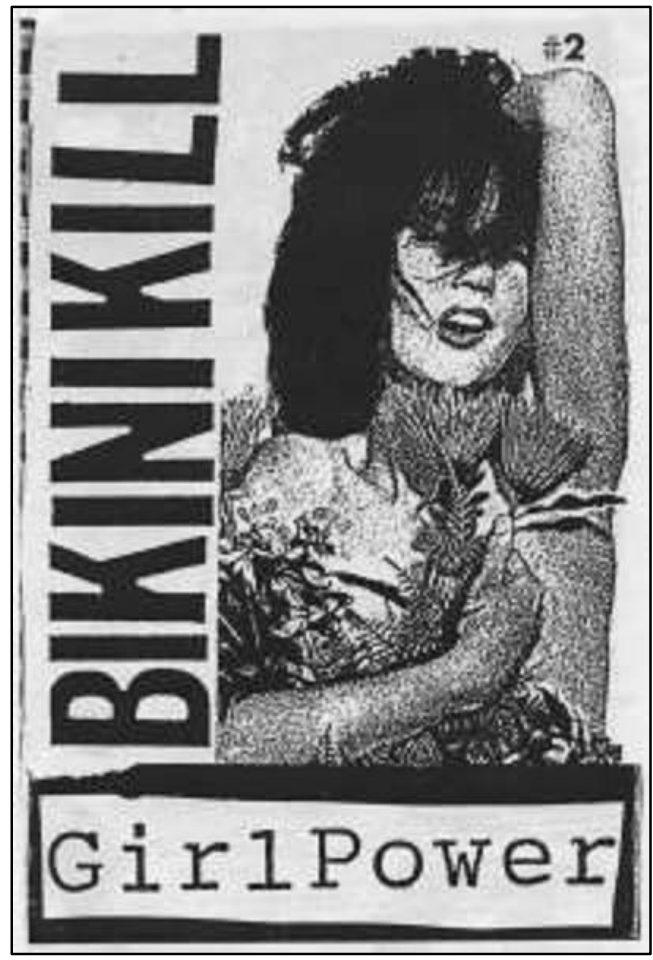

Figure2: Cover of Bikini Kill
Zines were important to the movement because riot grrrl existed on the belief that it only took one person living defiantly to radically change the world; the focus was action. It was not that one person's radical lifestyle would spread like wildfire, but that the action itself, in saying that "I will not live according to the status quo," was the first step to creating alternative communities. For example, on the page before the riot grrrl manifesto, one contributor writes, "I feel so many things, sadness and joy and excitement and anticipation, the J-word (jealousy). Left out" (Bikini Kill Zine \#2). These are feelings typical to adolescence, but when printed within the feminist zine they support the fight that says being a woman is somewhat isolating. It was not so much what was being said, but that a very important and ordinary someone was saying it-these riot grrrls were determining their existence on their own terms. Simultaneously, personal confessions like this became a way of intertwining the vulnerable (and feminine) with the zine \#2.

radically political nature of riot grrrl. As Stephen Duncombe
Politics of Alternative Culture, creating zines was a way "to reject definitions given by the dominant society and replace them with one's own" (Duncombe 73). The movement carved out a participatory space for the individual to express life as they saw it. Participation was so important because at some level an individual's choice to live differently is the most radical thing that can come out of a capitalist society. The fact that women were consenting to this lifestyle made it radical, each action becoming a political action in opposition to patriarchal oppression.

What Loy expressed in words became physically manifested in the action of riot grrrl. To note the difference between personal and public mediums of expression, I'll mention that Loy's radical manifesto and "Songs to Joannes" often overlap in message, but as works of art, they operate in completely different spaces, meaning they were not published in conjunction with one another. Loy never published her manifesto in fear that it would be horribly misunderstood. In comparison, the riot grrrl manifesto is tucked within pages of the zine itself-nestled between illegible poems, and confessions about experiences of sexual assault. The political cannot be separated from the personal in riot grrrl to an extent beyond the philosophical, because the physicality of both their stage performance and nature of the zines make this impossible. 
Just as the personal became intertwined with the political in zines, Bikini Kill's paradoxical lyrics embed themselves within Kathleen Hanna's stage performance. For a long time Hanna wrote most of her songs about sexual assault, something deeply personal yet undoubtedly the product of a sexist culture. Picture this: "Bikini Kill had played its first few songs fully clothed, but now, wearing just a skirt and a scalloped black bra, Kathleen turned to face the audience so everyone could see what was written on her

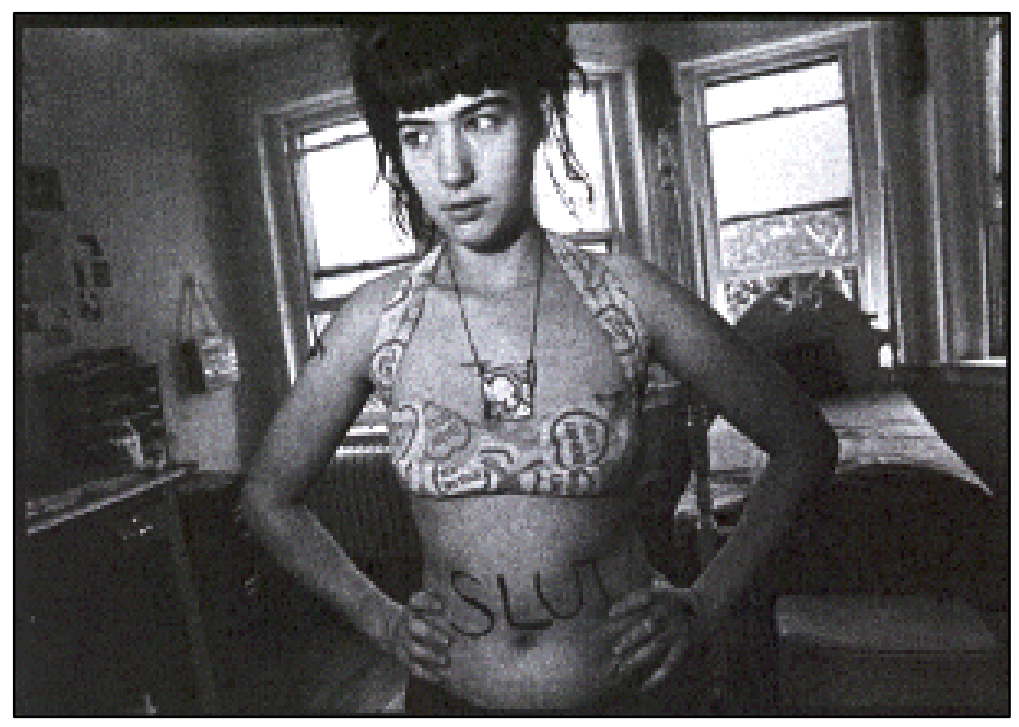

Figure 3: Bikini Kill lead singer Kathleen Hanna with "SLUT" written on her stomach. Photo taken by Linda Rosier, 1992. stomach: SLUT" (Marcus 75).

These stage antics forced the audience to make connections: we were calling victims of sexual assault sluts, but these victims were individuals, and they were not victims of isolated misfortune, they were victims of systematic oppression. Even further, in doing this Hanna was reclaiming the word "slut", saying, "because I like to have sex does not mean I deserve to be assaulted". If we look back to Loy, we can see the common theme of sexual shaming, and both of these women's attempts to deconstruct the false binary between the mistress and the mother.

Let's look now to the Bikini Kill song "Alien She." Here Hanna expresses her duality of identity-the girl who wants to "put the pretty, pretty lipstick on" and the one society calls, "'feminist' 'dyke' 'whore." The blurring of the lines occurs when Hanna cannot tell if she is participating or succumbing to typically feminine expression. Does she want to put the lipstick on, or is she pressured to? Even more complicated: does feminism pressure her to suppress her femininity? In the opening lines Hanna sings, "She is me / I am her" repeatedly, confusing the ability to ever separate the two. Isolating any one strict identity becomes impossible. One and the same, she yells, "Siamese twins connected at the cunt". This abrasive metaphor sums up the position of a cisgendered (a woman whose assigned birth sex matches her chosen gender identity) feminist woman in society. She is forced to be two women at once from birth onward. This life path is based, as Loy would agree, in her sex. Consciously choosing to live in line with a feminist philosophy, society makes it impossible to fully realize oneself as both a feminist, and as feminine. Going back to the word "cunt," let's look at Hanna's volatile diction. It is considered the most offensive word in the English language, and in using it, Hanna associates female sexuality with ugliness and shame, society's message to women. They have no choice in their assigned sex, and in making sex both their point of inferiority and point of worth, patriarchy sets up a nearly inescapable dynamic. As with Loy's character Pig Cupid in poem I, we can draw a direct connection between the functionality of reducing womanhood to sex in her poetry and Hanna's 
use of the word "cunt" in "Alien She." "Siamese twins" - the feminist and the typically feminine within Loy and Hanna are at odds, yet part of one another. This inescapable duality is heard in Hanna's voice when she begins the chorus, "I want to kill her / But I'm afraid it might kill me." Hanna expresses shame for her internalized sexism, while hesitantly questioning the possibilities of feminism itself. We need to make a clear distinction when reading this: it is not Hanna questioning the validity of feminism, but questioning the genuineness of her life choices as inherent to her being, rather than as products of her chosen politics. In the context of "the mistress" and "the mother," sentiments expressed in "Songs to Joannes" mirror the indecipherability of identity in "Alien She". To fully understand this, we must look at one of Loy's more sentimental poems: in poem XVI, Loy the romantic reminisces on a sentimental love that might have been:

\section{XVI \\ We might have lived together \\ In the lights of the Arno \\ Or gone apple stealing under the sea \\ Or played \\ Hide and seek in love and cob-webs \\ And a lullaby on a tin-pan \\ And talked till there were no more tongues \\ To talk with \\ And never have known any better}

Through Loy's sentimental diction, like her use of the phrase, "We might have..." in line 1, it is inferred that "Loy the feminist" and "Loy the romantic" are one and the same. In poem I Loy presents a feminist standpoint, then counters it with the sentimentality of "once upon a time." In XVI Loy uses the same strategy, only performed backwards. The poem is constructed entirely out of the sentimental, yet her inconclusive diction expresses an incongruity of identity. By beginning the poem with "We might have..." Loy negates the possibility that these dreams of going "apple stealing under the sea," and playing "Hide and seek in love and cob-webs" were realized. She wants to go apple stealing with her young lover-to get into harmless trouble. By situating this metaphor in the ocean, Loy conveys the sense that this is a separate and impossible world, one to which she does not belong. In the second metaphor Loy presents another innocent depiction of young love, but in using the word "cob-webs" suggests that young love is a notion long past. Selfdoubting, Loy still desires these things. As much as Loy the feminist tries to separate herself from the society that has created a false idealization of love, she is a participant in this society as wellpart of her identity is rooted within it, and this part of her continues to interject itself within her radical politics.

Loy's ability to express this dichotomy of identity through her poetry is inherent to the personality of the poetic medium. The ambiguity of poetic language allows for a multidimensional interpretation of each word, and consequently a live and experiential reading of each poem. The vitality of poem XVI is made apparent by her use of the conjunctions "or" and "and." Looking at the words themselves we can see how they are reflective of her internal struggle. She 
does not use the word "either" with "or"; the "or" "and" combination expresses the nuanced reality that she is not a feminist or a lover, but that she is a feminist and a lover. Let's look at the last line of poem XVI: "And never have known any better." Loy consciously recognizes her convoluted identity. Yes, it would be easier to not know any better, to be unaware of the power dynamics of society. Given her manifesto, the fact is Loy does know better. Her feminist philosophy does not negate her personality (her lived experience, her desire to love and be loved). Critical thought is at odds with basic human desire; this is not the fault of the individual, but rather the fault of an oppressive system. Here Loy discovers there is no perfect feminism without sacrifice.

In conclusion, let us examine the last line of "Alien She": "And all I really wanted to know / Who was me and who is she / I guess I'll never know." Hanna may never understand her identity conclusively, but she was participating in the process of both finding, and creating an identity for herself. In choosing to write SLUT on her stomach, she refused any attempt to remove her politics from her being. Through performance, despite internal conflict, her body stands as a political statement. The binary Loy described as "the mistress and the mother" comes to mind. To break down this false binary Hanna had made her physical self a political spectacle-she sacrificed sentimentality for her politics. Through performance, a philosophy isolated to Loy's mind and written work became the foundation for riot grrrl, and is now active, as opposed to being static on the bookshelf.

\section{WORKS CITED}

Bikini Kill. “Alien She”. Pussy Whipped. Kill Rock Stars, 1993. CD.

---. “Bikini Kill”. Zine \#2. Olympia, WA. 1991. Print.

Burke, Carolyn. Becoming Modern: The Life of Mina Loy. Berkeley, CA: University of California Press, 1997. Print.

Duncombe, Stephen. Notes From Underground: Zines and the Politics of Alternative Culture. ( $2^{\text {nd }}$ ed.). Bloomington, IN: Microcosm Publishing, 1997. Print.

Loy, Mina. The Lost Lunar Baedeker. New York, NY : Farrar, Straus, and Giroux, 1996. Print.

Marcus, Sara. Girls to the Front: The True Story of the RIOT GRRRL Revolution. New York, NY: Harper Collins Publishers, 2010. Print.

X-Ray Spex. “Oh Bondage Up Yours!” Oh Bondage Up Yours! Virgin, 1977. VS. 